\title{
Correction to: Spirosoma profusum sp. nov., and Spirosoma validum sp. nov., radiation-resistant bacteria isolated from soil in South Korea
}

\author{
Yuna Park - Soohyun Maeng - Tuvshinzaya Damdintogtokh • Jing Zhang • \\ Min-Kyu Kim • Sathiyaraj Srinivasan · Myung Kyum Kim
}

Published online: 15 July 2021

(C) Springer Nature Switzerland AG 2021

Correction to: Antonie van Leeuwenhoek (2021) 114:1155-1164 https://doi.org/10.1007/s10482-021-01585-9

In the original publication, the type strain "BT702 KCTC 82115" was incorrectly published, it should be "BT702 $2^{\mathrm{T}}$ KACC 22028". Similarly, the type strain
"BT704 ${ }^{\mathrm{T}}$ KCTC 82114" is incorrect, it should be "BT704 ${ }^{\mathrm{T}}$ KACC 22030".

The original article has been corrected.

Publisher's Note Springer Nature remains neutral with regard to jurisdictional claims in published maps and institutional affiliations.

The original article can be found online at https:// doi.org/10.1007/s10482-021-01585-9.

Y. Park · S. Maeng · T. Damdintogtokh .

J. Zhang · M.-K. Kim · S. Srinivasan (凶) ·

M. K. Kim $(\bowtie)$

Department of Bio and Environmental Technology,

College of Natural Science, Seoul Women's University,

Seoul 139-774, Republic of Korea

e-mail: drsrini@swu.ac.kr

M. K. Kim

e-mail: biotech@swu.ac.kr

J. Zhang · M. K. Kim

Radiation Research Division, Korea Atomic

EnergyResearch Institute, Jeongeup 56212, Republic of

Korea 